E3S Web of Conferences 1, 15010 (2013)

DOI: $10.1051 / \mathrm{e} 3$ sconf $/ 20130115010$

(c) Owned by the authors, published by EDP Sciences, 2013

\title{
Accumulation of polonium ${ }^{210} \mathrm{Po}$, uranium $\left({ }^{234} \mathrm{U}\right.$ and $\left.{ }^{238} \mathrm{U}\right)$ and plutonium $\left({ }^{238} \mathrm{Pu}\right.$ and $\left.{ }^{239+240} \mathrm{Pu}\right)$ in tissues and organs of deer Carvidae from northern Poland
}

\author{
D. I. Strumińska-Parulska, A. Boryło, B. Skwarzec and M. Prucnal
}

University of Gdańsk, Faculty of Chemistry, Sobieskiego 18/19, 80-952 Gdańsk, POLAND, strumyk@chem.univ.gda.pl

\begin{abstract}
Livers, kidneys and muscles of large herbivorous animals: roe deer (Capreolus capreolus), red deer (Cervus elaphus) and fallow deer (Dama dama), collected in northern Poland, were the subject of the investigation. Polonium, uranium and plutonium activities were measured using alpha spectrometry along with relevant radiochemical procedures. The average concentrations of ${ }^{210}$ Po ranged between $0.02 \pm 0.01 \mathrm{~Bq} \mathrm{~kg}^{-1} \mathrm{ww}$ in muscles and $7.15 \pm 0.12 \mathrm{~Bq} \mathrm{~kg}^{-1} \mathrm{ww}$ in kidneys. The concentration of ${ }^{238} \mathrm{U}$ ranged widely between $2.49 \pm 0.18$ and $69.37 \pm 5.45 \mathrm{mBq} \mathrm{kg}^{-1}$ ww. The average concentrations of ${ }^{239+240} \mathrm{Pu}$ ranged between $0.18 \pm 0.04 \mathrm{mBq} \mathrm{kg}^{-1}$ ww in muscle and $2.77 \pm 0.60 \mathrm{mBq} \mathrm{kg}^{-1}$ ww in kidneys. Statistical analysis showed that the sampling location, sex, age and species did not influence on the radioisotope activities in the analyzed samples.
\end{abstract}

Key words: polonium, uranium, plutonium, deer, Carvidae, bioaccumulation, Poland bioaccumulation

\section{Introduction}

Natural polonium and uranium as well as man-made plutonium are widespread all over the world, take part in geochemical circulation and accumulate in the food chain. Forests are vulnerable ecosystems. Areas covered in trees are traps for contamination transported in the air (Mirosławski et al., 1992). Radionuclides are much more persistent in forest ecosystems than in agricultural land (Strebl et al., 1996). Their cycling is almost closed. Moreover environment conditions favor the transfer of radionuclides to plants (Kiefer et al., 1996).

${ }^{210} \mathrm{Po}$ is naturally occurring alpha-emitting product of the ${ }^{238} \mathrm{U}$ decay chain. ${ }^{210} \mathrm{Po}$ is the important source of the internal radiation received by human beings, can be either ingested or inhaled by animals (Hill, 1966; Bernard, 1979). In mammals ${ }^{210}$ Po accumulates mainly in soft tissues such as liver and kidney (Bernard, 1979). Uranium is widely spread in nature, it occurs in over 160 minerals. Isotopes ${ }^{234} \mathrm{U}$ and ${ }^{238} \mathrm{U}$ occur in the natural uranium decay chain; both are alpha emitters of low radioactivity and radiotoxicity. In soils, sediments and waters metallic uranium corrodes and is transformed into U(VI) (Meinrath et al., 2003). Uranium is transported as the $\mathrm{UO}_{2}{ }^{2+}$ ion in a way similar to calcium, with which uranium competes (Edmands et al., 2001).

The main sources of plutonium in the atmosphere are nuclear weapon tests carried out among 1945-1962.
During this time, about $0.33 \mathrm{PBq}{ }^{238} \mathrm{Pu}$ and $13 \mathrm{PBq}$ ${ }^{239+240} \mathrm{Pu}$ were released. A high amount of plutonium was released also during the Chernobyl accident (Aarkrog, 1991). Due to the consumption of forest products or leaching of radionuclides into groundwater, forests also contribute to the internal human dose (Kiefer et al., 1996). Plutonium in the environment is mostly connected to soil, sediments or suspended matter (Choppin, 1985).

The aim of this investigation was to assess the level of radioactive contamination of the northern Poland and estimate the potential threat for game meat consumers, which is of importance because of its economical value.

\section{Material and Methods}

Kidney, liver and muscle tissues and organs samples were collected from 28 deer (17 specimens of red deer (Cervus elaphus), 8 specimens of roe deer (Capreolus capreolus) and 3 specimens of fallow deer (Dama dama)) obtained in the region of northern Poland (Białystok, Gdańsk, Olsztyn, Szczecin, Szczecinek, Toruń). All animal carcasses were routinely collected and partly dissected and all obtained samples of kidney, liver and muscle were used for polonium, uranium and plutonium analysis (Skwarzec and Prucnal, 2007; Skwarzec et al., 2010). The fresh samples were weighted, homogenized and digested using $65 \% \mathrm{HNO}_{3}$ with a ${ }^{209} \mathrm{Po}(50 \mathrm{mBq}),{ }^{232} \mathrm{U}(32.5 \mathrm{mBq})$ and ${ }^{242} \mathrm{Pu}(5 \mathrm{mBq})$ spikes added as a yield tracers. The 
radiochemical method allows $\mathrm{Po}, \mathrm{U}$ and $\mathrm{Pu}$ determination from the same sample (Skwarzec, 1997; Skwarzec and Prucnal, 2007; Skwarzec, 2009; Skwarzec et al., 2010). After radiochemical preparation, the activities of ${ }^{210} \mathrm{Po},{ }^{234} \mathrm{U},{ }^{238} \mathrm{U},{ }^{238} \mathrm{Pu}$ and ${ }^{239+240} \mathrm{Pu}$ radionuclides were measured separately using alpha spectrometer (Alpha Analyst, Canberra Packard) equipped with PIPS detectors. The accuracy and precision of the radiochemical method were evaluated using IAEA reference materials and estimated at less than $10 \%$.

\section{Results and Discussion}

${ }^{210} \mathrm{Po}$

The average results of ${ }^{210} \mathrm{Po}$ measurements in livers, kidneys and muscles of deer form northern Poland are given in Table 1 . The ${ }^{210} \mathrm{Po}$ concentrations in kidneys, livers and muscles of deer were independent of age of the animals. Polonium does not accumulate during the lifetime, it is short-living, and it is removed from body constantly. Similarly, there was no relationship observed between the accumulation of polonium in tissues and organs of deer and sex of the animals. Generally, values of ${ }^{210}$ Po concentrations in tissues and organs for both sexes were widely spread. Also concentrations of heavy metals such as cadmium, cobalt, copper, nickel and zinc in tissues of deer are usually independent of sex of the animal (Michalska and Żmudzki, 1992). Polonium is accumulated independently in all samples examined; there was no relationship between concentration of polonium in kidney and liver or muscles. This is the result of the fact that the retention of polonium and the biological half-times varies between tissues because of their physiological features (Blanchard, 1966). The difference in food preferences between all three species had no significant influence on accumulation of polonium. Animals were usually characterized by the highest concentration of ${ }^{210} \mathrm{Po}$ in kidneys while the lowest in muscles (Skwarzec and Prucnal, 2007). For human and others species of animals (caribou or reindeer) there were reverse tendency observed. Physiology of animals has influence on metabolism of polonium, and ruminants are characterized by specific physiology. For example, deer have no gall bladder, and the bile is the main factor which removes the polonium from liver (Bernard, 1979). Concentrations of ${ }^{210} \mathrm{Po}$ in tissues of deer were a little bit higher than those found in human tissues, especially in the case of kidneys (Hill, 1966). However, human and deer's muscle have similar levels of polonium. Moreover, the concentrations measured in muscles with the mean value of $0.16 \pm 0.15$ $\mathrm{Bq} \mathrm{kg}^{-1} \mathrm{ww}$ is approximately the same that in Polish beef $\left(0.10 \mathrm{~Bq} \mathrm{~kg}^{-1} \mathrm{ww}\right)$, pork $\left(0.09 \mathrm{~Bq} \mathrm{~kg}^{-1} \mathrm{ww}\right)$ and in meat from England and USA (0.11 $\left.\mathrm{Bq} \mathrm{kg}^{-1} \mathrm{ww}\right)$ (Pietrzak-Flis et al., 1997).
Table 1. The average concentrations of ${ }^{210} \mathrm{Po},{ }^{234} \mathrm{U},{ }^{238} \mathrm{U}$, ${ }^{238} \mathrm{Pu}$ and ${ }^{239+240} \mathrm{Pu}$ in tissues and organs of deer from northern Poland

\begin{tabular}{|c|c|c|c|}
\hline \multirow{2}{*}{ Isotope } & \multicolumn{3}{|c|}{$\begin{array}{c}\text { Tissue, organ average concentration } \\
\left(\mathrm{mBq} \mathrm{kg}{ }^{-1} \mathrm{ww}^{ \pm} \mathrm{SD}\right) \\
\text { (number of samples) }\end{array}$} \\
\hline & $\begin{array}{l}\text { Kidney } \\
\text { (n) }\end{array}$ & $\begin{array}{l}\text { Liver } \\
\text { (n) }\end{array}$ & $\begin{array}{c}\text { Muscle } \\
\text { (n) }\end{array}$ \\
\hline${ }^{210} \mathrm{Po}$ & $\begin{array}{c}1.58 \pm 1.14 \\
(46)\end{array}$ & $\begin{array}{c}1.08 \pm 1.12 \\
(46)\end{array}$ & $\begin{array}{c}0.16 \pm 0.15 \\
(21)\end{array}$ \\
\hline${ }^{234} \mathrm{U}$ & $\begin{array}{c}16.9 \pm 12.7 \\
(17)\end{array}$ & $\begin{array}{c}19.8 \pm 19.5 \\
(6)\end{array}$ & $\begin{array}{c}26.8 \pm 30.3 \\
(4)\end{array}$ \\
\hline${ }^{238} \mathrm{U}$ & $\begin{array}{c}19.4 \pm 17.9 \\
(17)\end{array}$ & $\begin{array}{c}17.7 \pm 16.9 \\
(6)\end{array}$ & $\begin{array}{c}23.6 \pm 22.0 \\
(4)\end{array}$ \\
\hline${ }^{238} \mathrm{Pu}$ & $\begin{array}{c}0.88 \pm 0.63 \\
(18)\end{array}$ & $\begin{array}{c}0.36 \pm 0.14 \\
\text { (12) }\end{array}$ & $\begin{array}{c}0.21 \pm 0.05 \\
\text { (13) }\end{array}$ \\
\hline${ }^{239+240} \mathrm{Pu}$ & $\begin{array}{c}1.62 \pm 0.89 \\
(18)\end{array}$ & $\begin{array}{c}0.60 \pm 0.32 \\
(12)\end{array}$ & $\begin{array}{c}0.56 \pm 0.59 \\
(13)\end{array}$ \\
\hline
\end{tabular}

${ }^{234} U$ and ${ }^{238} U$

The results of ${ }^{234} U$ and ${ }^{238} U$ radioactivity measurements in livers, kidneys and muscles of deer from northern Poland are given in Table 1 . Similarly to ${ }^{210} \mathrm{Po}$, the accumulation of ${ }^{234} \mathrm{U}$ and ${ }^{238} \mathrm{U}$ in the deer tissues and organs was independent of age and sex of animals. Similarly, there was no correlation between the organs or tissues examined and the amount of ${ }^{234} \mathrm{U}$ or ${ }^{238} \mathrm{U}$ accumulated (Skwarzec et al., 2010). In the stags, the concentration of ${ }^{238} U$ increased in order: muscle $<$ kidney $<$ liver, and in hind in order kidney $<$ liver $<$ muscle. The concentrations of uranium in tissues of deer from examined area were higher than these found in human soft tissues. The human body contains about $100 \mu \mathrm{g}$ of uranium: $7.4 \mathrm{mBq} \mathrm{kg}^{-1}$ in soft tissues and $150 \mathrm{mBq} \mathrm{kg}{ }^{-1}$ in bones (Meinrath, 2003). The deer's kidneys contained $19.4 \pm 17.9 \mathrm{mBq} \mathrm{kg}^{-1} \mathrm{ww}$ of ${ }^{238} \mathrm{U}$ and $16.8 \pm 12.7 \mathrm{mBq} \mathrm{kg}^{-1}$ ww of ${ }^{234} \mathrm{U}$.

In Poland the content of ${ }^{238} \mathrm{U}$ in beef is about 5.63 $\mathrm{mBq} \mathrm{kg}^{-1}$ ww. In pork, poultry and eggs the concentrations are about $0.62-1.78 \mathrm{mBq} \mathrm{k^{-1 }}$ ww (Pietrzak-Flis et al., 1997). These values are similar to the minimal values found in tissues and organs of the analyzed deer from northern Poland (Skwarzec et al., 2010). It may denote that wild ruminants could accumulate uranium more efficiently than non-ruminants and domestic ruminants. It is possible, that the longer food retention time in the alimentary tracts of ruminants enhances the efficiency of absorption of uranium and deteriorates the efficiency of removal, for example, in faeces. Wild ruminants also consume more plants with high amounts of uranium (i.e., cereal) or mushrooms compared to domestic animals (Pietrzak-Flis et al., 1997). The higher content of uranium in the food of wild ruminants could result in its higher transfer factors into the organism, because when uranium absorption becomes more efficient, the high amounts of uranium can handicap 
kidney function and the efficiency of uranium removal with urine (Arruda-Neto et al., 2001).

${ }^{238} \mathrm{Pu}$ and ${ }^{239+240} \mathrm{Pu}$

The results of ${ }^{238} \mathrm{Pu}$ and ${ }^{239+240} \mathrm{Pu}$ measurements in livers, kidneys and muscle deer from northern Poland are presented in Table 1. The activities of plutonium in many of the analyzed samples were below the detection limit. These data are similar or slightly lower than the ${ }^{239+240} \mathrm{Pu}$ concentrations measured in deer's bones by Mietelski et al. (2000). The Chernobyl plutonium contribution varied from $44 \%$ to $82 \%$ in kidneys, 64 $68 \%$ in livers and $91 \%$ in muscles indicating the significant impact of the Chernobyl accident on the northern part of Poland and the plutonium transport in the ecosystem (Skwarzec et al., 2010). The big fraction of Chernobyl plutonium in the analyzed deer could be also caused by its high concentrations in the plants which are an important part of the diet of the deer: berries (Vaccinium spp.), tree bark or needles (Komosińska and Podsiadło, 2002). In leaves of the blueberry $(V$. myrtillus $)$ the ${ }^{239+240} \mathrm{Pu}$ concentrations varied from 3.4 to $11 \mathrm{mBq} \mathrm{kg}^{-1} \mathrm{dw}$, in the lingonberry ( $V$. vitis-idaea) the concentration was $21.6 \mathrm{mBq} \mathrm{kg}^{-1} \mathrm{dw}$. In pine (Pinus sylvestris) and spruce (Picaea excelsa) needles the plutonium concentration was higher sometimes over $100 \mathrm{mBq} \mathrm{kg}{ }^{-1} \mathrm{dw}$, spruce bark contained $208 \mathrm{mBq} \mathrm{kg}^{-1} \mathrm{dw}$ of ${ }^{239+240} \mathrm{Pu}$. In ferns (Athyrium $\mathrm{sp}$ ). from the north-eastern Poland the plutonium concentration was even higher than in the spruce and equaled $244 \mathrm{mBq} \mathrm{kg}^{-1} \mathrm{dw}$ of ${ }^{239+240} \mathrm{Pu}$ (Mietelski et al., 1993).

\section{Radiation Doses}

The total natural radiation exposure in Poland leads to an effective dose of about $2.8 \mathrm{mSv}$ year $^{-1}$, and the consumption of game animal meat in Poland is about $0.08 \mathrm{~kg}$ per year, which constitutes $0.12 \%$ of the total meat consumption (Jagielak et al., 1998; Czeraszkiewicz, 2002).

Table 2. Estimated mean annual individual effective doses in humans caused by the consumption of $1 \mathrm{~kg}$ game meat

\begin{tabular}{|l|c|c|c|}
\hline \multirow{2}{*}{$\begin{array}{c}\text { Mean annual } \\
\text { effective dose } \\
(\mu \mathrm{Sv})\end{array}$} & \multicolumn{3}{|c|}{ Tissue, organ } \\
\cline { 2 - 4 } & Kidney & Liver & Muscle \\
\hline${ }^{210} \mathrm{Po}$ & 1.9 & 1.3 & 0.2 \\
\hline${ }^{234} \mathrm{U}$ & $0.8310^{-3}$ & $0.9710^{-3}$ & $1.3110^{-3}$ \\
\hline${ }^{238} \mathrm{U}$ & $0.8810^{-3}$ & $0.7810^{-3}$ & $1.0610^{-3}$ \\
\hline${ }^{238} \mathrm{Pu}$ & $2.0110^{-4}$ & $0.8310^{-4}$ & $0.4810^{-4}$ \\
\hline${ }^{239+240} \mathrm{Pu}$ & $3.9910^{-4}$ & $1.5010^{-4}$ & $1.4010^{-4}$ \\
\hline
\end{tabular}

The annual individual effective dose due to ingestion of ${ }^{210}$ Po in $1 \mathrm{~kg}$ game meat (muscle, liver or kidney) depends upon the concentration of the radionuclide (Table 2). The effective doses from $1 \mathrm{~kg}$ of deer meat were calculated at in the case of kidney $1.9 \mu \mathrm{Sv}$, in the case of liver $1.3 \mu \mathrm{Sv}$ and in the case of muscle $0.2 \mu \mathrm{Sv}$ and are generally small and equal only $0.0053-0.0007 \%$ of the natural radiation dose (Table 2). The value of effective dose of ${ }^{210} \mathrm{Po}$ ingested by eating game meat is small in comparison to the dose received by mushrooms consumers $(37 \mu \mathrm{Sv}$ per year) (Skwarzec and Jakusik, 2003).

Effective dose due to ingestion of ${ }^{234} \mathrm{U}$ and ${ }^{238} \mathrm{U}$ were also calculated and presented in Table 2. Assuming that game meat corresponds to deer meat, it can be calculated that it would be a source of effective dose of $0.78 \cdot 10^{-3}$ $1.06 \cdot 10^{-3} \mu \mathrm{Sv}$ (from decay of ${ }^{238} \mathrm{U}$ ) and $0.83 \cdot 10^{-3}-1.31 \cdot 10^{-}$ ${ }^{3} \mu \mathrm{Sv}$ (from decay of ${ }^{234} \mathrm{U}$ ). The annual individual effective dose from ${ }^{234} \mathrm{U}$ and ${ }^{238} \mathrm{U}$ in game meat accounts only $1.86 \cdot 10^{-5} \%$ of the total annual effective dose from all natural sources in Poland (Jagielak et al., 1998). This indicates that the uranium in the tissues of deer from northern Poland presents no radiological risk for their consumers.

Based on the data the annual effective doses for ${ }^{238} \mathrm{Pu}$ and ${ }^{239+240} \mathrm{Pu}$ were calculated as well (Table 2). The biggest values of effective dose were obtained for kidneys while the smallest for muscles. The annual individual effective dose would be $0.48 \cdot 10^{-4}-2.01 \cdot 10^{-4} \mu \mathrm{Sv}$ (from ${ }^{238} \mathrm{Pu}$ ) and $1.40 \cdot 10^{-4}-3.99 \cdot 10^{-4} \mu \mathrm{Sv}$ (from ${ }^{239+240} \mathrm{Pu}$ ). This would yield only $1.71 \cdot 10^{-6} \%$ (muscles) and $7.18 \cdot 10^{-6} \%$ (liver and kidney) of the total annual individual effective dose from all natural sources (Jagielak et al., 1998). This indicates that there is no radiological risk coming from plutonium radionuclides contained in deer meat for the population.

\section{Acknowledgments}

The authors would like to thank the Ministry of Science and Higher Education for the financial support under grant DS/8120-4-0176-12.

\section{References}

1. Aarkrog A. Source of terms and inventories of anthropogenic radionuclides. Environmental Science and Technology Department/Ecology Section. Risø National Laboratory, Roskilde, Denmark; 1991.

2. Arruda-Neto JDT, Likhachev VP, Nogueira GP, Araujo GW, Camargo SP, Cavalcante GT, Cestari AC, Craveiro AM, Deppman A, Ferreira JW, Garcia F, Geraldo LP, Guzman F, Helene OM, Manso MV, Martins MN, Mesa J, Oliveira MF, Perez G, Rodriguez O, Tavares MV, Vanin VR. Transfer coefficient measurements of uranium to the organs of Wistar rats, as a function of the uranium content in the food. Appl Radiat Isot 2001;54:947.

3. Bernard SR. A Metabolic Model for Polonium. Health Phys 1979:36:732. 
4. Blanchard RL. Relationship between ${ }^{210} \mathrm{Po}$ and ${ }^{210} \mathrm{~Pb}$ in man and his environment. In: Radioecological concentration processes. Stockholom 25-29 April 1966;281.

5. Choppin GR. Speciation of plutonium in seawater and freshwater. Environ Inorg Chem 1965:307.

6. Czeraszkiewicz R. Sympozjum w Kamiennym Moście. Brać Łowiecka 2002:8.

7. Edmands JD, Brabander DJ, Coleman DS. Uptake and mobility of uranium in black oaks: implications for biomonitoring depleted uranium-contaminated groundwater. Chemosphere 2001:44:789.

8. Hill CR. Routes of uptake of ${ }^{210} \mathrm{Po}$ into human tissues. In: Radioecological concentration processes. Stockholom, 25-29 April 1966:297.

9. Kiefer P, Prohl G, Muller H, Lindner G, Drissner J, Zibold G. Factors affecting the transfer of radiocaesium from soil to roe deer in forest ecosystems of southern Germany. Sci Tot Environ 1996;192:49.

10. Komosińska H, Podsiadło E. Ssaki kopytne. PWN:2002.

11. Meinrath A, Schneider P, Meinrath G. Uranium ores and depleted uranium in the environment, with a reference to uranium in the biosphere from the Erzgebirge/Sachsen, Germany. J Environ Radioact 2003:64:75.

12. Michalska K, Żmudzki J. Zawartość metali w tkankach dzików, saren i jeleni w rejonie wielkopolskim. Medycyna Weterynaryjna 1992;48(4).

13. Mietelski JW, LaRosa JJ, Ghods A. Results of ${ }^{90} \mathrm{Sr}$ and ${ }^{238} \mathrm{Pu},{ }^{239+240} \mathrm{Pu},{ }^{241} \mathrm{Am}$ measurements in some samples of mushrooms and forest soil from Poland. J Radioanal Nucl Chem 1993;170(1):243.
14. Mietelski JW, Gaca P, Jasińska M. Plutonium and other alpha-emitters in bones of wild, herbivorous animals from north-eastern Poland. Appl Radiat Isot 2000;53(1-2):251.

15. Mirosławski J, Cyganek M, Czomperlik B, Szywała A, Kwapuliński J. Ocena emisjochłonnej funkcji lasu w aspekcie zagrożenia toksycznymi metalami ciężkimi. Sylwan 1992;5: 11.

16. Jagielak J, Biernacka M, Henschke J, Socińska A. Radiologiczny Atlas Polski. PIOŚ, CLOR, PAA. Warszawa:1998.

17. Pietrzak-Flis Z, Chrzanowski E, Dembińska S. Intake of ${ }^{226} \mathrm{Ra},{ }^{210} \mathrm{~Pb}$ and ${ }^{210} \mathrm{Po}$ with food in Poland. Sci Tot Environ 1997;203:157.

18. Skwarzec B. Radiochemical methods for the determination of polonium, radiolead, uranium and plutonium in environmental samples. Chem Anal (Warsaw) 1997;42:107.

19. Skwarzec B. Determination of radionuclides in aquatic environment. In: Analytical measurement in aquatic environments. Tylor\&Francis PE 2009: 241.

20. Skwarzec B, Jakusik A. ${ }^{210}$ Po bioaccumulation by mushrooms from Poland. J Enviton Monit 2003;5:791.

21. Skwarzec B, Prucnal M. Accumulation of polonium ${ }^{210} \mathrm{Po}$ in tissues and organs of deer Carvidae from Northern Poland. J Environ Sci Health B 2007;42:335.

22. Skwarzec B, Boryło A, Prucnal M, StrumińskaParulska D. Accumulation of uranium $\left({ }^{234} \mathrm{U},{ }^{238} \mathrm{U}\right)$ and plutonium $\left({ }^{239+240} \mathrm{Pu}\right)$ in tissues and organs of deer /Cervidae/ from northern Poland. Pol J Environ Stud 2010;19(4):771.

23. Strebl F, Gerzabek MH, Karg V, Tataruch F. ${ }^{137} \mathrm{Cs}-$ migration in soils and its transfer to roe deer in an Austrian forest stand. Sci Tot Environ 1996;181:23 